\title{
Aborsi Kriminalis Provokatus Pada Remaja Putri (Studi Kualitatif Di Kabupaten Polewali Mandar)
}

\author{
Suryadi \\ Institut Agama Islam DDI Polewali Mandar \\ e-mail-nersadhy@gmail.com
}

\begin{abstract}
ABSTRAK
Penelitian ini mengungkap Jenis Kasus abortus (keguguran) dapat terjadi dimana saja dan kapan saja baik di Negara yang sudah maju maupun negara yang sedang berkembang. Aborsi merupakan salah satu topik yang selalu hangat dan menjadi perbincangan di berbagai kalangan masyarakat. Penelitian ini bertujuan untuk mengetahui Pengetahuan, Sikap, Akses Informasi, Teman sebaya, Keluarga dan Kesehatan Reproduksi remaja tentang aborsi Kriminalis Provokatus pada remaja di Kota Polewali Mandar. Penelitian ini adalah penelitian kualitatif, Penentuan informan dalam penelitian ini menggunakan teknik purposive sampling, Subjek penelitian adalah remaja yang melakukan tindakan aborsi kriminalis provokatus dan kasus tersebut terjadi antara tahun 2017-2018 dengan jumlah total Informan 8 orang. Teknik pengambilan data dilakukan dengan wawancara mendalam menggunakan pedoman wawancara. Hasil penelitian menunjukkan bahwa penyebab terjadinya aborsi pada remaja adalah perilaku seksual berisiko, pengetahuan yang kurang tentang aborsi, sikap remaja yang permisif, akses media informasi tentang aborsi, sikap orang tua, dan perilaku teman dekat dan kurangnya Informasi tentang Kesehatan reproduksi dan seksualitas.
\end{abstract}

Kata Kunci: Aborsi, Remaja Putri

\section{PENDAHULUAN}

Di era globalisasi ini generasi muda yang merupakan penerus bangsa dihadapkan pada pesatnya informasi tentang berbagai hal, termasuk hal-hal yang menyangkut seksual yang dapat memberikan pengaruh baik positif maupun negatif. Selain itu remaja juga memiliki rasa ingin tahu yang tinggi, terutama dalam masalah seks. Informasi yang mereka dapat bisa dari berbagai sumber dan diterima begitu saja tanpa menyaringnya.

WHO memperkirakan ada 20 juta kejadian aborsi tidak aman di dunia, 9,5 \% (19 dari 20 juta tindakan aborsi tidak aman) diantaranya terjadi di Negara berkembang. Sekitar 13\% dari total perempuan yang melakukan aborsi tidak aman berakhir dengan kematian. Resiko kematian akibat aborsi yang tidak aman di wilayah Asia di perkirakan 1 berbanding 3700 dibanding dengan aborsi yang aman.

Kepala Badan Koordinasi Keluarga Berencana Nasional (BKKBN) Sul-Sel, mengaku perihatin dengan keberadaan remaja saat ini. Sebab menurut data 2010, baik dari Badan Pusat Statistik (BPS) sebagian dari 63 juta jiwa remaja berusia $10-24$ tahun di indonesia berprilaku tidak sehat. Kasus aborsi dikalangan remaja, diperoleh data 2,5 juta jiwa perempuan pernah melakukan aborsi dan dari jumlah ini $27 \%$ atau 700 ribu dilakukan remaja. 
Di Indonesia sendiri pada tahun 2011, dilakukan di Jakarta diperoleh hasil bahwa sekitar 620 persen anak SMU dan Mahasiswa di Jakarta pernah melakukan hubungan seks pranikah. Sebanyak 35 persen dari mahasiswa kedokteran di sebuah perguruan tinggi swasta di Jakarta sepakat tentang seks pranikah. Dari 405 kehamilan yang tidak direncanakan, 95 persennya dilakukan oleh remaja usia 15-25 tahun. Angka kejadian aborsi di Indonesia mencapai 2,5 juta kasus, 1,5 juta diantaranya dilakukan oleh remaja. Lalu, polling yang dilakukan di Bandung menunjukkan, 20 persen dari 1.000 remaja yang masuk dalam polling pernah melakukan, seks bebas. Diperkirakan 5-7 persennya adalah remaja di pedesaan. Sebagai catatan, jumlah remaja di Kota Polewali Mandar sekitar 700.000. Berarti, bisa diperkirakan jumlah remaja yang melakukan seks bebas sekitar 38-53 ribu. Kemudian, sebanyak 200 remaja putri melakukan seks bebas, setengahnya kedapatan hamil dan 90 persen dari jumlah itu melakukan aborsi.

Abortus di Indonesia bukan masalah baru, sejak lama sudah terdapat obat-obatan (ramuan) tradisional yang berkhasiat menggugurkan kandungan Ini berarti praktek abortus sudah lama terjadi di Indonesia, saat ini abortus masih merupakan masalah besar di Indonesia hal ini berkaitan dengan praktek abortus sering di lakukan oleh generasi muda apalagi pelajar, Angka kejadian abortus provokatus kriminalis di Indonesia mencapai 2,5 juta kasus pertahun, atau 43 abortus untuk setiap 100 kehamilan dan sekitar 30\% di antara kasus abortus itu di lakukan oleh penduduk usia 15-24 tahun. Data itu berdasarkan survey dengan cakupan relative terbatas. Data yang komprehensif tentang kejadian abortus di Indonesia tidak tersedia $(5,12,13)$.

Abortus di Indonesia bukan masalah baru, sejak lama sudah terdapat obat-obatan (ramuan) tradisional yang berkhasiat menggugurkan kandungan Ini berarti praktek abortus sudah lama terjadi di Indonesia, saat ini abortus masih merupakan masalah besar di Indonesia hal ini berkaitan dengan praktek abortus sering di lakukan oleh generasi muda apalagi pelajar, Angka kejadian abortus provokatus kriminalis di Indonesia mencapai 2,5 juta kasus pertahun, atau 43 abortus untuk setiap 100 kehamilan dan sekitar 30\% di antara kasus abortus itu di lakukan oleh penduduk usia 15-24 tahun.

Kejadian aborsi di Kota Polewali Mandar dilaporkan sekitar 300 kasus, namun untuk kasus aborsi secara ilegal tidak ditemukan data secara pasti sebab tidak tercatat dan tidak dilaporkan, pergaulan bebas merupakan salah satu faktor penyebabnya ditambah lagi dengan tidak adanya kontrol dari keluarga, dimana kebanyakan yang melakukan aborsi secara ilegal adalah mahasiswa.

Kejadian aborsi di Kota Polewali Mandar, tepatnya di kelurahan Polewali cukup memprihatikan, karena dilakukan pada usia sangat muda yaitu 15-18 tahun masi relatif mudah, dan organ reproduksi atau rahim belum terbentuk dengan baik, dan masi tergolong pelajar. Selain itu, faktor pengetahuan remaja juga menjadi salah satu faktor penyebab terjadinya kehamilan yang tidak diinginkan, dan melakukan tindakan aborsi sebagai pilihan, banyak informasi dari berbagai media memudakan remaja di Kota Polewali Mandar muda mendapat tempat dan cara melakukan aborsi, sebab kebanyakan remaja belum mendapatkan pendidikan seks baik di lingkungan keluarga maupun sekolah sebab masih dianggap sesuatu yang tabu untuk diperbincangkan.

Kasus abortus (keguguran) dapat terjadi dimana saja dan kapan saja baik dinegara yang sudah maju maupun negara yang sedang berkembang. Abortus adalah keluarnya janin sebelum mencapai viabilitas dimana masa gestasi belum mencapai usia 22 minggu dan beratnya kurang dari $500 \mathrm{~g}$. Secara hukum abortus adalah tindakan menghentikan kehamilan atau mematikan janin sebelum 
waktu kelahiran tanpa melihat usia kandungannya. abortus dapat terjadi secara alami (spontaneus), dapat pula terjadi karena dibuat/disengaja (abortus provocatus).

Abortus provokatus kriminalis yaitu abortus yang dilakukan tanpa indikasi medis. Abortus provokatus dibagi menjadi dua yaitu provokatus medisinalis (terapeutik) dan abortus provokatus kriminalis. Secara statistik $40 \%$ dari semua kasus abortus merupakan abortus provokatu kriminalis (Mochtar, R.2009) Di kalangan ahli kedokteran dikenal dua macam abortus (keguguran kandungan) yakni abortus spontan dan abortus buatan. Abortus spontan adalah merupakan mekanisme alamiah yang menyebabkan terhentinya proses kehamilan sebelum berumur 28 minggu. Penyebabnya dapat oleh karena penyakit yang diderita si ibu ataupun sebab-sebab lain yang pada umumnya berhubungan dengan kelainan pada sistem reproduksi.

Definisi sikap menurut Soetarno (1994) adalah pandangan atau perasaan yang disertai kecenderungan untuk bertindak terhadap obyek tertentu. Sikap senantiasa diarahkan kepada sesuatu artinya tidak ada sikap tanpa obyek. Sikap diarahkan kepada benda-benda, orang, peritiwa, pandangan, lembaga, norma dan lain-lain.

Selain pendidikan, akses informasi mempengaruhi tingkat pengetahuan seseorang berdasarkan penerimaan informasi dari akses informasi tersebut. Adapun sumber informasi yang dapat mempengaruhi misalnya media cetak dan, media elektronik. Media massa Sesuai dengan perkembangan heterogen seksualitasnya, remaja menikmati media massa (televisi, radio, surat kabar, majalah, internet, foto). Keingintahuan tenang seksual merupakan pendorong bagi remaja untuk memanfaatkan media tersebut dalam pemenuhan kebutuhannya.

Kesehatan reproduksi remaja adalah suatu kondisi sehat yang menyangkut sistem, fungsi dan proses reproduksi yang dimiliki oleh remaja. Pengertian sehat tidak semata-mata berarti bebas penyakit atau bebas darikecacatan namun juga sehat secara mental serta sosial kultural. Remaja perlumengetahui kesehatan reproduksi agar memiliki informasi yang benar mengenaiproses reproduksi serta berbagai faktor yang berhubungan. Dengan informasiyang benar, diharapkan remaja memiliki sikap dan tingkah laku yang bertanggungjawab mengenai proses reproduksi.

Berdasarkan latar belakang masalah diatas, maka penulis tertarik untuk meneliti bagaimana aborsi kriminalis provokatus pada remaja puteri di Kota Polewali Mandar.

\section{METODE PENELITIAN}

Jenis dan rancangan penelitian menggunakan jenis penelitian kualitatif, adalah untuk melihatgambaran fenomena (termasuk kesehatan) yang terjadi di dalam suatu populasi tertentu. Penelitian Kualitatif juga dapat didefinisikan suatu penelitian yang dilakukan untuk mendeskripsikan atau menggambarkan suatu fenomena yang terjadi di dalam masyarakat. Studi ini menggunakan rancangan penelitian studi kasus yaitu, penggalian data dan informasi mengenai Aborsi Kmiminalis Provokatus pada remaja Putri. Penelitian ini dilaksanaan di Kota Polewali mandar.

Informan dalam penelitian ini dibagi dua kategori yaitu informan utama dan informan kunci. Penentuan Informan dilakukan dengan teknik Purposive sampling, Karateristik informan utama adalah remaja perempuan yang berdomisili di Kota Polewali Mandar adalah usia 17-19 tahun mengalami kasus aborsi krminalis provokatus. 
Teknik pengumpulan data yang dilakukan dalam penelitian ini adalah peneliti membuat sebuah panduan wawancara mendalam yaitu berupa kerangka atau garis besar proses wawancara dan isi wawancara. Panduan ini berisi pertanyaan yang digunakan peneliti sebagai acuan dalam menggali informasi dari subjek penelitian. Pokok-pokok pertanyaan yang diberikan kepada remaja yang mengalami aborsi krminalis provokatus berkenaan dengan pergaulan teman dekat. Peneliti akan menanyakan hal-hal yang berfokus pada aborsi kriminalis provokatus pada remaja putri.

\section{HASIL DAN PEMBAHASAN}

Pengumpulan data dari informan menggunakan metode indepth interview (wawancara mendalam). Pemilihan subjek penelitian dilakukan dengan menemukan informan kunci terlebih dahulu, yaitu seorang teman yang pernah melakukan aborsi di salah satu tempat di Kota Makassar. Remaja tersebut memiliki beberapa data teman-teman dalam hal ini remaja yang pernah melakukan aborsi krminalis provokatus karena mengalami kehamilan tidak diinginkan. melalui informan kunci inilah peneliti selanjutnya diberikan informasi mengenai remaja yang mengalami kehamilan tidak diinginkan, dan melakukan aborsi kriminalis provokatus selanjutnya peneliti mengunjungi tempat tinggal remaja yang bersangkutan.

Informan A saat ini berusia 19 tahun. Ia mengalami kasus kehamilan tidak diinginkan pada akhir tahun 2014 dan melalukan aborsi disuatu tempat yang di bantu oleh seorang dukun, saat itu dia sedang duduk di bangku kulia. Informan A tinggal bersama pacarnya di kos-kosan, Informan melakukan aborsi disebabkan karena takut sama kelurga, malu, masih kulia. Informan B saat ini berusia 17 tahun, duduk di bangku kelas 1 SMA. Ia mengalami kasus kehamilan tidak diinginkan pada awal tahun 2014, dan ia melakukan aborsi dengan minum ramuan dan Obat-obatan. Informan C saat ini berusia 19 tahun, Ia mengalami kasus kehamilan tidak diinginkan pada akhir tahun 2015 melakukan aborsi di dukun mengalami Pendarahan yang hebat dan di rujuk ke Bps Sekar dan di berikan perawatan. Informan D saat ini berusia 18 tahun, mengalami kasus kehamilan tidak diinginkan pada awal tahun 2015 dan melakukan aborsi dengan meminum obat dan makan nanas mudah, minum minumam beralkohol, Informan mengalamai pendarahan dan di bawah ke Bidan Praktek Swasta, mendapatkn pertolongan, yang pada saat itu dia sedang duduk bangku kelas 3 SMA. Informan dalam penelitian terbagi dua karakteristik yaitu: Pertama, Karateristik Informan Utama Informan utama dalam penelitian ini adalah remaja perempuan yang berdomisili di Kota Polewali Mandar dengan usia 17-19 tahun berjumlah empat orang. remaja yang dipilih merupakan remaja yang mengalami kasus kehamilan tidak diinginkan dan melakukan tindakan abori provokatus kriminalis. Kedua, Karateristik Informan Kunci Informan kunci merupakan kelompok informan yang digunakan sebagai cross check atas fakta-fakta yang diperoleh di lapangan. Dalam penelitian ini, informan triangulasi berjumlah delapan orang, meliputi empat orangtua dan empat teman dekat dari informan utama.

Dalam penelitian ini ada empat informan yang melakukan tindakan aborsi berisiko. Mereka pernah melakukan kissing, neckingsampai intercourse. Ada tiga informan yang menyatakan bahwa melakukan tindakan aborsi berisiko atas dasar keterpaksaan, takut, malu kepada keluarga, dan teman. Berikut adalah kutipan pernyataan informan: 
"Aborsi provokatus kriminalis, merupakan menggugurkan kandungan secara sengaja, dampak dari aborsi yaitu pendarahan yang hebat, infeksi, dan shok. alasan melakukan aborsi kerena takut, malu punya anak di luar nikah dengan keluarga sangat marah".

Informan memiliki pengetahuan yang cukup baik mengenai aborsi kriminalis provokatus maupun dampak dari aborsi, penyebab dari aborsi dan alasan melakukan aborsi, malu punya anak di luar nikah, takut dimarahin orang tua, dan masih sekolah.

"Aborsi provokatus kriminalis adalah menggugurkan kandungan secara Sengaja dan membunuh Jahin yang belum lahir, dampak dari aborsi yaitu pendarahan, infeksi dan kematian mendadak, alasan melakukan aborsi yaitu masi kulia, pacar belum mau menikah, pacar kabur saat tahu hamil".

Informan memiliki pengetahuan yang cukup baik mengenai aborsi kriminalis provokatus, penyebab, dan dampak apabila melakukan pada dukun atau sediri dengan tidak aman dan beresiko, dan alasan melakukan aborsi, karena takut, malu dengan keluarga dan belum mau punya anak, karana masi kulia.

"Abosi provokatus kriminalis merupakan, Pengguguran kandungan atau mengakhiri kehamilan, dampak dari aborsi kematian, mandul, pendarahan, upaya pencegahan yaitu jauhkan pergaulan bebas dan seks bebas".

Informan memiliki pengetahuan yang kurang baik mengenai aborsi kriminalis provokatus, penyebab dari aborsi, dampak dan upaya pencegahan. (1) Sikap Informan tentang aborsi provokatus kriminalis. Sikap informan mengulas tentang pandangan informan mengenai aborsi dan alasan informan melakukan tindakan aborsi. Dalam penelitian ini didapatkan hasil sebanyak tiga informan menunjukkan sikap yang permisif terhadap tindakan aborsi. walaupun informan menganggap tidak boleh dilakukan namun mereka tetap memutuskan untuk melakukan hal tersebut karena berbagai alasan seperti atas dasar keterpaksaan karena takut dengan kelurga, malu, belum menikah aib kelurga. Bahkan salah satu informan menuturkan tidak merasa menyesal telah melakukan karena itu hal yang biasa yang. Berikut kutipan pernyatannya:

"Melakukan aborsi Itu tindakan yang jahat sebenarnya tidak boleh soal nya itukan merupakan, tindakan, kejahatan atau Kriminal dan membuhuh, sama sekali tidak berpikiran untuk melakukan hal seperti itu tapi yang penting aman, berjalan begitu saja. biasa saja kerena sudah terjadibanyak teman melakukan aborsi juga baek2 ji sikapnya cuek dan menganggap hal yang biasa".

Sikap informan yang permisif yaitu informan menganggap aborsitidak boleh dilakukan namun mereka tetap memutuskan untuk melakukan hal tersebut karena berbagai alasan seperti malu, takut sama orang tua, tidak ada pilihan.

"Mestinya nggak boleh melalukan hubungan seks di luar nikah, dan melakukan aborsi tapi sama-sama suka sudah hamil jadi milih aborsi. Mungkin itulah solusi yang tepat, yang penting bisa tetap sekolah, semoga tidak ada pelaku aborsi lagi dan yang membantu harus dihukum berat biar tidak ada korban lagi".

Sikap informan yang permisif yaitu informan menganggap aborsi tidak boleh dilakukan namun mereka tetap memutuskan untuk melakukan hal tersebut karena berbagai alasan seperti malu, takut sama orang tua, dan masi sekolah. 
"Informan mengatakan tidak bolehmelakukan hubungan di luar nikah tapi karena sayang dan cinta, lakukan suka sama suka, sudah positif hamil tidak ada pilihan jadi harus melakukan aborsi sudah terlanjur, malu, masi Sekolah takut di bunuh orang tua".

Sementara sebanyak satu informan memiliki sikap tidak permisif terhadap seks dan tindakan aborsi. Informan menganggap hubungan seksual tidak boleh dilakukan sebelum menikah namun karena paksaan dari pasangannya dan sangat mencintai pasangannya sehingga informan menuturi kemauan pasangan untuk melakukan aborsi padahal secara sadar informan tidak memiliki niat untuk melakukan tindakan aborsi. Dalam hal ini pasangan informan sangat berpengaruh untuk melakukan aborsi. Berikut kutipan pernyataan informan:

"Hubungan seksual di luar nikah dan melakukan aborsi tidak boleh karena perbuatan yang tidak baik, dan abrosi itukan membunuh, tapi belum nikah takut dan sayang sama pacar, mau pertahankan kehamilan tapi di ancam, saya juga masi sekolah jadi terpaksa”.

Sikap informan yang tidak permisif yaitu informan menganggap aborsi tidak boleh dilakukan namun karena paksaan dari pasangannya dan takut diputusin sehingga informan menuturi kemauan pasangan untuk melakukan aborsi.

Hasil penelitian menunjukkan bahwa Pengetahuan informan kurang baik mengenai tindakan aborsi yang dilakukan oleh empat informan berada dalam tahap berisiko dan melakukan tindakanan kejahatan, tapi kurangnya pengetahuan mereka menganggap hal biasa tidak berbahaya. Selain itu empat informan sering melakukan aborsi dengan berbagai cara rata-rata mereka melakukan aborsi lebih dari satu kali tapi merka tidak mengetahui dampak dari aborsi tersebut. Minimnya pengetahuan tentang bahaya aborsi, sehingga informan berkali-kali melakukan aborsi. Semua informan pertama kali melakukan aborsi pada usia yang relatif muda yaitu kurang dari 18 tahun. Ada dua informan melakukan aborsi pertama kali pada usia 17 tahun sedangkan dua informan lain melakukan aborsi pertama kali pada usia16 tahun.

Hanya pengetahuan tentang aborsi yang di lakukan tahu tidak boleh di lakukan, kapan dan mengapa di lakukan sebanyak empat informan dapat menjawab dengan benar. Hal ini diperkuat dengan pendidikan terakhir yang ditempuh informan yaitu sebanyak tiga informan hanya mampu mengetahui sebatas mereka karena di SMA atau di bangku Kulia ,tidak ada mata kulia tentang kesehatan reproduksi.sedangkan satu informan hanya Tingkat SMA dikarenakan terjadinya kasus kehamilan melakukan aborsi yang tidak diinginkan pada pada Informan,saat informan duduk di bangku SMA sehingga mereka terpaksa harus keluar dari sekolah, dan tidak dapat melanjutkan pendidikan.

Tingkat pendidikan yang tinggi memungkinkan remaja lebih banyak menerima informasi kesehatan reproduksi dan seksual baik dari sekolah maupun orangtua, teman sebaya dan media sehingga informasi yang diterima dapat mempengaruhi perilaku remaja dalam perkembangannya. Oleh karena itu, dapat disimpulkan bahwa rendahnya pengetahuan responden tentang kesehatan reproduksi dan seksualitas merupakan salah satu faktor yang mempengaruhi terjadinya kehamilan tidak diinginkan pada remaja.

Perilaku Remaja yang dilakukan dengan unsur kesenggajan yang Berkali-kali (aborsi) oleh remaja dibawah usia 17 tahun secara medis dapat memperbesar kemungkinan terkena infeksi menular seksual dan virus HIV (Human Immuno Deficiency Virus). Selain itu dapat merangsang tumbuhnya sel kanker pada rahim remaja perempuan karena pada remaja prempuan usia 12-17 tahun mengalami 
perubahan aktif pada sel dalam mulut rahimnya. Hal ini karena pada saat usia muda, sel-sel rahim masih belum matang. Sel-sel tersebut tidak rentan terhadap zat-zat kimia yang dibawa oleh sperma dan segala macam perubahannya. Jika belum matang, bisa saja ketika ada rangsangan sel yang tumbuh tidak seimbang dengan sel yang mati, dengan begitu maka kelebihan sel ini bisa berubah sifat menjadi sel kanker dan kemandulan. Selain itu informan menuturkan bahwa ketika melakukan aborsi informan tidak konsisten dalam menggunakan obat-obatan dan ramuan bahkan tidak memikirkan dampak akan terjadi dalam aborsi tersebut. Sebanyak dua informan tidak pernah bayangkan hal-hal yang akan dia alami saat melakukan aborsi, sedangkan dua informan jarang atau tidak konsisten dalam melakukan aborsi pada sat itu yang penting selesai danbisa tenang tidak buat malu keluarga. Pada dasarnya informan mengetahui bahwa aborsi titu tindakan yang sangat tidak baik, membuat dosa, dan kejahatan, namun tetap melakukan, menolak untuk dinikahi dan juga tidak ada kemauan informan untuk mempertahankan kehamilanya saat itu.

Aborsi merupakan pilihan utama bagi mereka yang telah Mengetahui hamil terutama bagi yang belum menikah. Namun umumnya remaja tidak merencanakan hubungan seks terlebih dahulu terjadi tanpa direncanakan atau tanpa diinginkan sehingga tidak siap dengan melakukan aborsi maupun lain dan yang belum berpengalaman melakukan aborsi cenderung mempertahankan kehamilan tersebut dan menikah secara baik-baik. Padahal pemakaian dengan mempertahankan kehamilan itu sangat baik, pada saat melakukan aborsi diperlukan untuk mencegah terjadi pendarahan, dan kematian karena remaja putri mempunyai resiko lebih tinggi terhadap pendarahan, infeksi karena alat dan proses aborsi tidak hygenis dan tidak aman, dibandingkan wanita yang lebih tua karena belum matangnya sistem reproduksi.

Sikap informan tentang aborsi kriminalis provokatus berdasarkan penelitian ini, sebanyak tiga informan menunjukkan sikap yang permisif terhadap aborsi. Sikap informan yang permisif menganggap aborsi tidak boleh dilakukan karena itu berbahaya namun mereka tetap memutuskan untuk melakukan hal tersebut karena berbagai alasan seperti atas dasar paksaan, takut, malu dan belum mau punya anak. Bahkan informan tidak merasa menyesal telah melakukan aborsi yang bisa menyebabkan kematian atau penjara.

Sedangkan satu informan menunjukkan sikap tidak permisif terhadap aborsi, Sikap informan yang tidak permisif menganggap kejahatan tidak boleh dilakukan namun karena paksaan dari pasangannya dan merasa takut, dan malu dan di oleh pasangannya sehingga informan menuturi kemauan pasangan untuk melakukan aborsi.

Cara terbaik untuk melindungi remaja dari gangguan kesehatan reproduksi adalah dengan memberikan informasi mengenai kesehatan reproduksi secara benar dan transparan. Informasi yang tepat juga akan membantu remaja dalam mengambil keputusan yang tepat mengenai segala hal yang berhubungan dengan kesehatan reproduksinya sehingga mereka dapat melindungi diri dari kehamilan tidak diinginkan, aborsi tidak aman, infeksi menular seksual. Perilaku yang didasari oleh kesadaran dan pengetahuan akan bertahan lama atau melekat pada individu tersebut.

Adanya sikap yang permisif terhadap aborsi dan didukung pengetahuan yang kurang tentang kesehatan reproduksi mendorong informan untuk melakukan tindakan aborsi tanpa mngetahui dampak dari aborsi tersebut. 
Akses informasi tentang aborsi kriminalis provokatus, perkembangan teknologi yang semakin maju dan memudahkan masyarakat untuk mengakses segala informasi dengan cepat tidak terkecuali informasi mengenai aborsi. Dalam penelitian ini ada tiga informan yang mengaku pernah mengakses internet tentang aborsi.

Informan mengaku sering mengakses internet bersama pasangan dan temannya. Selain itu membicarakan hal-hal yang berkaitan dengan aborsi dan obat, ramuan, dan dukun yang membantu aborsi juga sering dilakukan oleh informan bersama teman-temannya.

Tidak hanya informan yang pernah mengakses media informasi tentang aborsi melainkan teman dekat informan juga pernah mengaksesnya, seperti membaca komik yang di dalamnya terdapat gambar-gambar Aborsi serta sering. Tentu hal ini akan secara tidak langsung akan mempengaruhi perilaku informan dalam hal akses informasi tentang aborsi karena hampir setiap hari menghabiskan waktu bersama teman-temannya. Sehingga dapat disimpulkan jika informan juga sering mengakses media informasi mengenai Aborsi maupun membicarakan hal-hal yang berkaitan dengan aborsi.

Menurut Nugraha Media Masa adalah tulisan, gambar, televisi, atau bentuk komunikasi lain yang melukiskan orang, sebagian besar perempuan, laki-laki dan anak-anak, dalam pose yang erotis (menggairahkan secara seksual) atau aktivitas seksual yang menyimpang dari apa yang disebut sehat dan normal. Membaca dan melakukan Aborsi atau menyebabkan orang terbiasa atau berperilaku agresif secara sengaja.

Remaja mulai ingin tahu tentang kehidupan seksual manusia, dan melakukan aborsi. Untuk itu, mereka mencari informasi mengenai seks, baik melalui buku, film, atau gambar-gambar lain yang dilakukan secara sembunyi-sembunyi. Hal ini dilakukan remaja karena kurangnya terjalin komunikasi yang bersifat dialogis antara remaja dengan orang dewasa, baik orangtua maupun guru, mengenai masalah aborsi, dimana sebagian besar masyarakat masih menganggap tabu untuk membicarakan masalah seksual dalam kehidupan sehari-hari. membicarakan seks dan aborsi juga harus dalam konteks ilmiah atau belajar untuk memahami diri dan orang lain, serta pemanfaatan secara baik dan benar sesuai dengan fungsi dan tujuan yang baik.

Hal ini dapat disimpulkan bahwa remaja yang terpapar aborsi lebih beresiko berperilaku seksual, dan aborsi berisiko dibandingkan dengan remaja yang tidak terpapar dengan aborsi. Makin meningkatnya remaja yang terpapar aborsi merupakan suatu masalah besar yang berkontribusi terhadap meningkatnya jumlah remaja yang berperilaku seksual aktif, dan aborsi. Dengan demikian perilaku seksual aktif ini akan mendorong remaja untuk melakukan hubungan seksual pranikah yang salah satu dampaknya kehamilan tidak diinginkan pada remaja.

Ada dua informan yang sering menghabiskan waktu bersama teman-temannya dengan nongkrong atau kumpul-kumpul di depan kos-kosan. mereka selalu menceritakan hal-hal yang berhubungan dengan seks dan aborsi tempat-tempat aborsi.Ada satu dari tiga orang informan yang juga sering mengabiskan waktu dengan mengunjungi pergi ke tempat wisata di daerah pegunungan yang memang dikenal sering dijadikan tempat muda-mudi berpacaran dan sering kali dipakai untuk berbuat yang tidak selayaknya (mesum). Kebiasaan ini dapat mendorong remaja ke hal-hal negatif karena mereka juga mengajak pasangan ketika menghabiskan waktu bersama teman-teman. Tentu hal ini akan memicu terjadinya aktivitas seksual yang dilakukan oleh remaja mulai dari yang ringan seperti berfantasi, berpegangan tangan hingga yang berisiko seperti kissing sampai intercourse. 
Selain itu perilaku seksual teman sebaya informan berada dalam tahap berisiko. Mereka mengaku pernah melakukan hubungan seksual pranikah dengan pacar, dan sering melakukan aborsi. tidak hanya teman dekat, perilaku seksual teman sebaya informan juga sudah diambang batas yaitu pernah melakukan hubungan seksual pranikah, dan melakukan aborsi. Bahkan teman sebaya menganggap bahwa remaja yang melakukan hubungan seksual pranikah seperti hal yang sudah biasa di kalangan mereka saat ini.

Remaja yang melakukan perilaku seks pranikah dapat termotivasi oleh pengaruh kelompok dalam upaya ingin menjadi bagian dari kelompoknya dengan mengikuti norma-norma yang telah dianut oleh kelompoknya (melakukan perilaku seks pranikah). Selain itu, didorong oleh rasa ingin tahu yang besar untuk mencoba segala hal yang belum diketahui. Pada masa remaja, kedekatan dengan peer-group sangat tinggi karena selain ikatan peer-group menggantikan ikatan keluarga, juga merupakan sumber afeksi, simpati, dan pengertian, saling berbagi pengalaman dan sebagai tempat remaja untuk mencapai otonomi dan independensi.

Dengan demikian remaja mempunyai kecenderungan untuk mengadopsi informasi yang diterima oleh teman-temannya, tanpa memiliki dasar informasi yang signifikan dari sumber yang lebih dapat dipercaya.

Berdasarkan hasil penelitian ini, sebanyak tiga informan menuturkan bahwa orang tuanya kurang peduli dengannya. Orangtua juga membeda-bedakan dalam hal rasa kasih sayang terhadap anak-anaknya, Rasa sayang tersebut tidak menyeluruh karena ayah maupun ibu memiliki rasa sayang yang berbeda antara anak pertama dengan anak yang kedua. Bahkan salah satu orangtua informan sering melakukan kekerasan terhadap anaknya seperti menampar, memukul dan menjambak rambut. Selain itu orangtua tidak pernah memantau kegiatan sehari-hari anak. Mereka menganggap remaja tidak suka dikekang sehingga cukup memberi kepercayaan kepada anaknya. Selain itu mereka menuturkan bahwa anak sulit untuk diatur dan diberi nasihat hingga akhirnya orangtua tidak peduli atau masa bodoh dengan kegiatan yang dilakukan anak sehari-hari.

Hanya satu informan memiliki orangtua yang memperhatikan dan menjalin kedekatan emosional dengan baik. Namun, karena faktor ekonomi yang menurun orangtua lalai dalam memperhatikan kegiatan sehari-hari anak sehingga tidak dapat memonitoring kegiatan di luar dengan baik. Di sisi lain pemberian informasi mengenai kesehatan reproduksi dan seksualitas tidak diberikan secara mendetail oleh orangtua. Sebagian besar hanya menyampaikan masalah pubertas yaitu menstrulasi pada remaja. Selain itu penyampaian tentang bahaya seks pranikah dan larangan melakukan aborsi juga tidak disampaikan secara detail kepada anak.

Hal ini disebabkan oleh beberapa kendala diantaranya orangtua menganggap usia anak masih belum dewasa sehingga belum membutuhkan informasi tersebut. Ditambah lagi kurangnya kedekatan orangtua dengan anak menyebabkan tidak terjalinnya hubungan komunikasi yang baik sehingga anak cenderung tidak memperdulikan nasihat yang disampaikan oleh orangtua. kurangnya pendidikan dan pengetahuan orangtua tentang Kesehatan reproduksi, sehingga tidak memberitahu anak atau melarang anaknya melakukan hal-hal yang berbahaya dan melakukan tindakan aborsi.

Peran orang tua berperan penting dalam pemberian informasi kepada remaja tentang kesehatan reproduksi dan seksualitas karena hubungan seksual. Pranikah yang mengakibatkan kehamilan tidak diinginkan dilakukan aborsi remaja tidak berdasarkan pada pengetahuan bagaimana 
cara untuk mencegah kehamilan. Kurangnya komunikasi secara terbuka antara orangtua dengan anak dalam masalah seksual dapat memperkuat munculnya penyimpangan perilaku seksual dan aborsi.

Orang tua memiliki tanggung jawab yang besar untuk mengasuh dan merawat serta memberikan pendidikan yang terbaik kepada anaknya. Orangtua juga berperan sebagai teladan dalam hal tanggung jawab bagi anaknya saat berinteraksi dengan anak sehari-hari. Anak-anak melewatkan banyak waktu untuk memperhatikan perilaku orangtua dan menirunya. Jika orangtua melakukan tugasnya dengan baik, komitmen dan kemungkinan besar, anak akan cenderung meniru karakter tersebut.

Pengetahuan informan diperoleh berdasarkan pengalaman yang dialami oleh informan, dari hasil penelitian sebanyak empat informan memiliki pengetahuan yang kurang baik mengenai kesehatan reproduksi dan seksualitas. Mereka tidak dapat menjelaskan apa yang dimaksud dengan kehamilan serta proses kehamilan dengan benar. Ketika diberikan pertanyaan mengenai definisi aborsi dan risiko yang ditimbulkan ada dua informan yang tidak dapat menjawab dengan baik. Selain itu sebanyak empat informan tidak dapat menjelaskan definisi Kesehatan Reproduksi.

Hanya pengetahuan tentang aborsi yang di lakukan tahu tidak boleh dilakukan, kapan dan mengapa dilakukan sebanyak empat informan dapat menjawab dengan benar. Hal ini diperkuat dengan pendidikan terakhir yang ditempuh informan yaitu sebanyak tiga informan hanya mampu mengetahui sebatas mereka karena di SMA atau di bangku Kuliah, tidak ada mata kuliah tentang kesehatan reproduksi. Sedangkan satu informan hanya tingkat SMA dikarenakan terjadinya kasus kehamilan melakukan aborsi yang tidak diinginkan pada pada Informan,saat informan duduk di bangku SMA sehingga mereka terpaksa harus keluar dari sekolah, dan tidak dapat melanjutkan pendidikan.

Tingkat pendidikan yang tinggi memungkinkan remaja lebih banyak menerima informasi kesehatan reproduksi dan seksual baik dari sekolah maupun orangtua, teman sebaya dan media sehingga informasi yang diterima dapat mempengaruhi perilaku remaja dalam perkembangannya. Oleh karena itu, dapat disimpulkan bahwa rendahnya pengetahuan responden tentang kesehatan reproduksi dan seksualitas merupakan salah satu faktor yang mempengaruhi terjadinya kehamilan tidak diinginkan pada remaja.

Remaja perlu mendapatkan informasi dan pengetahuan yang berhubungan dengan perilaku hidup sehat bagi remaja, di samping mengatasi masalah yang ada. Dengan pengetahuan yang memadai dan adanya motivasi untuk menjalani masa remaja secara sehat, para remaja diharapkan mampu memelihara kesehatan dirinya agar dapat memasuki masa kehidupan berkeluarga dengan reproduksi yang sehat. Selain itu informasi menyesatkan yang memicu kehidupan seksualitas remaja yang semakin meningkat dari berbagai media, yang apabila tidak diikuti dengan tingginya pengetahuan yang tepat dapat memicu perilaku Aborsi yang tidak bertanggung jawab dan salah satunya berdampak pada terjadinya kehamilan tidak diinginkan pada remaja.

Pengetahuan seksual yang benar dapat memimpin seseorang ke arah perilaku aborsi yang rasioal dan bertanggung jawab serta dapat membantu membuat keputusan pribadi yang terkait seksualitas. Sebaliknya, pengetahuan seksual yang salah dapat mengakibatkan kesalahan persepsi tentang seksualitas yang selanjutnya akan menimbulkan perilaku seksual yang salah dengan segala akibatnya. 


\section{PENUTUP}

\section{A. Simpulan}

Berdasarkan hasil penelitian, diperoleh kesimpulan bahwa aborsi Kriminalis Provokatus pada remaja Putri di Kota Polewali Mandar adalah sebagai berikut:

1. Pengetahuan informan menunjukan kurang baik mengenai aborsi yang dilakukan, dan dampak dari aborsi. Empat melakukan tindakan kejahatan, tapi kurangnya pengetahuan mereka menganggap hal biasa tidak berbahaya.

2. Sikap yang permisif terhadap aborsi, sikap informan yang permisif menganggap aborsi tidak boleh dilakukan karena itu berbahaya namun mereka tetap memutuskan untuk melakukan hal tersebut karena berbagai alasan seperti atas dasar paksaan, takut, malu dan belum mau punya anak.

3. Akses media informasi mengenai aborsi sangat mendukung, dan memudakan remaja untuk mengakses dan membaca, tentang aborsi dan tempat aborsi, ada dua informan yang mengaku pernah mengakses media serta membicarakan hal-hal yang berkaitan dengan seksualitas, dan aborsi.

\section{B. Saran}

Berdasarkan hasil penelitian terkait Abortus Kriminalitas, maka disarankan sebagai berikut.

1. Membuka wawasan baru tentang kesehatan reproduksi remaja yaitu dapat dimulai dengan membaca dari berbagai sumber tentang informasi tersebut yang nantinya dapat disampaikan kepada anak sebagai bekal ilmu maupun pencegahan dari masalah seksualitas remaja.

2. Pelaku aborsi agar dihukum berat. Hukuman berat tersebut menjadi contoh bagi orang lain yang berkeinginan melakukan aborsi sehingga mereka menjadi takut untuk melakukannya.

3. Untuk Dinas Pendidikan Kota Polewali Mandar. Mencanangkan kebijakan baru berkaitan dengan pendidikan kesehatan reproduksi untuk remaja misalnya dengan menyisipkan materi pendidikan kesehatan reproduksi dalam kegiatan ekstrakurikuler sebagai upaya untuk mencegah terjadinya aborsi pada remaja di Kota Polewali Mandar.

\section{DAFTAR PUSTAKA}

Arlin, Adam dkk. Buku Panduan Penyelesaian Studi FKM UPRI Makassar. Makassar: UP2, 2016.

Anonim. Faktor yang Mendorong Aborsi. Online.http://sarlito.hyperphp.com/ articles/ socialprocesses-and-social issues/aborsi.html

Anonim. Gugur Kandungan. Online. http://id.wikipedia.org/wiki/aborsi

Azinar, M. (2013). Perilaku Seksual Pranikah Berisiko Terhadap Kehamilan Tidak Diinginkan, (Online), Vol. 8, No. 2, hal 154-160, diakses 31 Maret 2016,

Adiwiyoto, A. How to Teach Children Responsibility. Jakarta: Mitra Utama, 2001.

Bidan Praktek Sekar Kota Makassar. Data rekamedik Bidan Praktek Sekar Kota Makassar. 2016. 
Bimantoro. Anak Hamil Sebelum Menikah, Reformata Edisi 156 Tahun X, 2012.

Bachtiar, A. Sukses Gaya Remaja Lima Prinsip Sukses Remaja dalam Studi, Karier dan Hidup. Jogjakarta: Saujana, 2005.

BKKBN (2014). Kajian Profil Penduduk Remaja (10-24 tahun): Ada apa dengan remaja? Desember 2011, diakses tanggal 1 Maret 2016.

Dewi, AP. (2012). Hubungan Karateristik Remaja, Peran Teman Sebaya, danPaparan Pornografi dengan Perilaku Seksual Remaja di Kelurahan Pasir Gunung Selatan Depok, (Online), diakses tanggal 30 Juni 2015.

Husaeni, L. Depresi pada Remaja Putri yang Hamil di Luar Nikah, (Online) diakses tanggal 30 Januari 2015.

IDAI. Kesehatan Reproduksi Remaja dalam Aspek Sosial. 10 September 2013.

Ismani, Nila. Etika Keperawatan. Jakarta: Widya Medika, 2000. 